\title{
Optimal operation of CVT-based powertrains
}

\section{Doctoral Thesis}

Author(s):

Pfiffner, Rolf Andreas Josef

Publication date:

2001

Permanent link:

https://doi.org/10.3929/ethz-a-004142150

Rights / license:

In Copyright - Non-Commercial Use Permitted 
Diss. ETH No. 14136

\title{
Optimal Operation of CVT-Based Powertrains
}

\author{
A dissertation submitted to the \\ SWISS FEDERAL INSTITUTE OF TECHNOLOGY \\ ZÜRICH
}

for the degree of

Doctor of Technical Sciences

\author{
presented by \\ Rolf Andreas Josef Pfiffner \\ Dipl. El.-Ing. ETH
}

born 18. January 1969

citizen of Mels and Mels-Weisstannen SG

accepted on the recommendation of

Prof. Dr. L. Guzzella, examiner

Prof. Dr. H. P. Geering, co-examiner 


\section{Abstract}

This thesis analyzes the fuel-optimal operation of powertrains that are equipped with a Continuously Variable Transmission (CVT). Although the use of CVTs is commonly considered as a promising approach for the improvement of the fuel economy of passenger cars, the operation mode that achieves minimum fuel consumption is known for stationary vehicle conditions only. For transient vehicle conditions, however, three approaches have been proposed so far. All of them rely on heuristic arguments, and the reasoning for fuel-optimality is based on "quasi static" considerations only. A truly dynamic solution is not yet available.

In order to fill this gap, a detailed model of the complete powertrain is developed and a meaningful performance index (cost function) is defined. The fuel-optimal control problem for transient vehicle operation is brought into an appropriate mathematical framework, i.e., it is formulated as a nonlinear optimal control problem which is then solved for various predefined vehicle trajectories using state-of-the-art numerical optimization software.

These investigations are carried out for a representative of the class of lightweight passenger cars. Within these investigations, two different engines types are considered: one is a conventional SI engine and the other is a downsized supercharged (DSC) SI engine. In both cases, the optimal solutions are shown to be superior to standard CVT control algorithms, yielding larger gains in fuel economy for DSC engines.

The optimal control problem has been solved for various different transient vehicle trajectories. Common features of these solutions are identified. They have been used to derive a causal suboptimal control strategy that realizes almost the same benefits in fuel economy, but requires a substantially reduced computational effort. Hence, it is realizable on-line.

On the basis of a comparison between the suboptimal control strategy and the classical control strategies, some adjustments for the 
well-known classical single track modified control strategy are proposed. The resulting improvements in fuel consumption are similar to those of the suboptimal control strategy. 


\section{Zusammenfassung}

Das Thema der vorliegenden Arbeit ist der verbrauchsoptimale Betrieb von Fahrzeugantrieben, die mit einem stufenlosen Getriebe ausgestattet sind. Obwohl die Anwendung von stufenlosen Getrieben als ein vielversprechender Ansatz zur Verbrauchsverbesserung von Personenkraftwagen angesehen wird, ist die verbrauchsoptimale Strategie nur für stationäre Fahrzustände bekannt. Für transiente Fahrvorgänge wurden bis anhin drei Steuerstrategien angewendet, die auf heuristischen Überlegungen aufgebaut sind. Die Grundlage dieser Strategien besteht in der Annahme von „quasistationären“ Fahrzeugbedingungen. Die dynamische Lösung war bisher nicht bekannt.

Zur Lösung des dynamischen Problems wurde ein Modell des gesamten Fahrzeugantriebes entwickelt sowie ein sinnvoller Güteindex (Kostenfunktion) definiert. Durch diese Massnahmen konnte das dynamische Problem in eine geeignete mathematische Darstellung überführt werden, d.h. es wurde als nichtlineares dynamisches Optimierungsproblem formuliert. Die Lösung dieses Problems wurde unter Verwendung moderner Optimierungssoftware für verschiedene Fahrzeugtrajektorien berechnet.

Die Berechnungen wurden für einen typischen Vertreter der Kleinwagenklasse durchgeführt, wobei zum einen ein konventioneller Verbrennungsmotor, zum anderen ein hubraumverkleinerter und aufgeladener Motor betrachtet wurde. Die optimale Lösung ergibt für beide Motorkonzepte im Vergleich zu konventionellen Steuerstrategien eine Verbrauchsminderung. Die Einsparung ist im Falle des hubraumverkleinerten und aufgeladenen Motors grösser als für den konventionellen Motor.

Anhand der optimalen Lösungen für verschiedene Fahrzeugtrajektorien wurden Charakteristika der optimalen Lösung identifiziert, welche die Herleitung einer suboptimalen Steuerstrategie erlaubten. Die suboptimale Steuerstrategie ist im Gegensatz zur Berechnung der optimalen Lösung in Echtzeit realisierbar, wobei die Verbrauchseinsparung nur marginal abnimmt. 
xii

Der Vergleich der suboptimalen Steuerstrategie mit den klassischen Steuerstrategien ermöglichte eine Weiterentwicklung der bekannten single track modified Steuerstrategie. Mit diesem modifizierten Algorithmus können ähnliche Verbrauchseinsparungen wie bei der suboptimalen Steuerstrategie erreicht werden. 